\title{
The Effects of Corporate Social Responsibility on Financial Performance on Indonesian Public Listed Tobacco Companies
}

\author{
Siti Maimunah Yahya Senawat* \\ Faculty of Economics and Business, \\ Universitas Padjadjaran, Bandung, Indonesia
}

\author{
Srihadi Winarningsih Zarkasyi \\ Faculty of Economics and Business, \\ Universitas Padjadjaran, Bandung, Indonesia
}

\author{
Ida Farida Abdul Gafur \\ Faculty of Economics, \\ Universitas Pakuan, Bogor, Indonesia
}

\begin{abstract}
This research aims to examine the effect of Corporate Social Responsibility (CSR) information revealed in the company's annual report on company financial performance. CSR is proxies in an independent variable which are Economy performance (X1), Environment Performance (X2) and Social Performance (X3). On the other hands, financial performance is proxies by four dependent variables, which are the Current Ratio (Y1), Debt Ratio (Y2), Net Profit Margin (Y3) and Return on Assets (Y4) on tobacco listed in Indonesia Stock Exchange. Research method used is panel data analysis using EViews 9 software. Purposive sampling is chosen, and three companies are used as the sample. Data used in this research is an annual financial report of tobacco sub-sector companies audited in the 2010-20117 period. Based on the examination report CSR can only explain one of four financial performance measurements, that is Debt Ratio around 62.6\%. Meanwhile, for other financial performance measurements such as the Current Ratio, Net Profit Margin and Return on Asset, CSR has not explained. All and all it can be concluded that CSR activity cannot quite describe company's financial performance. It can be seen through hypothesis testing result (test- $F$, test- $t$ ) as well as the measurement of data panel model goodness as in determination coefficient ( $R$-Square). The findings are helpful for policymakers to improve the financial performance of the organizations.
\end{abstract}

Keywords: Corporate social responsibility, current ratio, debt ratio, net profit margin, return on assets

Received: 8 October 2018; Accepted: 22 November 2018; Published: 15 December 2018

\section{INTRODUCTION}

When a company earns profits or maximum profits, the level of social inequality and environmental damage is even higher because of the company's activities that are not controlled by various resources to increase company profits. In addition to parties directly related to the company, the community and the environment around the company also feel the impact caused by the company's operations. It is intended that the company is not only required to focus on improving and improving the internal conditions of the company or in terms of seeking profit, but also the company is required to focus on developing social relations on the external conditions of the company which are corporate social responsibility to stakeholders. Social responsibility both internally and externally is called CSR.

CSR is a commitment of a company or business world (corporation) to contribute to sustainable economic development by paying attention to corporate social responsibility and emphasizing a balance between attention to economic, social and environmental aspects (Fahmi, 2013; Yoo, Lee, \& Lee, 2016). Companies that have carried out

\footnotetext{
${ }^{*}$ Correspondence concerning this article should be addressed to Siti Maimunah Yahya Senawat, Doctoral Student at Faculty of Economics and Business, Universitas Padjadjaran, Bandung, Indonesia. E-mail: siti.maimunah@unpak.ac.id
}

(c) 2018 The Author(s). Published by KKG Publications. This is an Open Access article distributed under a Creative Commons Attribution-NonCommercial-NoDerivatives 4.0 International License. 
CSR activities believe that no company can stand alone and be sustainable without being part of a wider community conducting its business activities. Implementation of social responsibility is an investment for the future and also an opportunity to ensure that the company and the community can grow together and support each other.

Corporate social responsibility itself can be described as the availability of financial and non-financial information related to organizational interactions with the physical environment and social environment, which can be expressed in the company's annual report. The disclosure is supported by (Hang, 2015; Ikatan Akuntan Indonesia, 1998) states that, "Companies can also provide additional financial reports such as reports on the environment and value added statements, especially for industries where environmental factors play an important role and for industries that consider employees as a group of financial report users."

Stakeholder's awareness of the importance of continuous development encourages companies to reveal practice of CSR. The stronger stakeholders's pressure in uncovering CSR practice makes it necessary to insert social element in companies' responsible into account. Then, company social responsibility report is only done voluntarily, now the government realize the importance and benefit of CSR report. It is supported with the legalization of several regulations that regulates the revealing of CSR by companies. In Indonesia, the awareness of keeping the environment is regulating under limited company regulation (Ketsiri \& Pajongwong, 2016; Republic Indonesia, 2007), in which a company that has a trading activity in the field of natural resources, comply to do social and environmental responsibility. CSR revealing done by companies is not only done to comply to the rule and regulation, but also as a long-term investment for them.

CSR activity shows that a company has concerned with the environment and people welfare around the area as well as the welfare of their employee. In other words, the benefit not only can be enjoyed by internal party but also all people. However, there might still a chance of CSR revealing which has not been a concern for a company to report it, while this revealing is very important in determining the value of Corporate Social Disclosure Index (CSDI). If CSDI value is good, it can give positive impact on company's reputation such as attracting investors as well as sustaining good reputation in the society. The application of CSR has been proven to improve a company's reputation (Carroll \& Shabana, 2010; Mohamed \& Arafa, 2016; Servaes \& Tamayo, 2013). Other than improving company's reputation, the benefits of applying CSR (Kotler \& Lee, 2008) are:

1. Increased sales and market share

2. Strengthened brand positioning

3. Increased ability to attract, motivate and retain employees

4. Decreased operating costs

5. Increased appeal to investors and financial analyst.

The challenge in starting CSR activity is to choose social issue to support. Some considerations in determining social issue such as:

1. Does the issue support business goal?

2. How large does the social problem sosial?

3. Has it been handled by the government?

4. How would the stakeholder respond if the company handles this kind of issue?

5. Can it make employee interested?

6. Has it been addressed by?

The issue is also supported with legitimation theory statement that to be accepted by the society, a company has to reveal their social activity to ensure the company's life (Dianita, 2015; Reverte, 2009). Legitimation will be received if there are similarities between the results and people expectation from the company, and therefore no one presses charges. A company can offer social sacrifice as a reflection of their concern on the society.

CSR concepts guide a company to not only have a short term goal which is to gain profit, but also apply three basic principles known as triple bottom line (profit, people and planet). A company that has long-term orientation instead of pursuing profit must also participate in the fulfillment of people welfare and preservation of the environment (planet) also known as 3P (Velasques, 2012).

Information on CSDI based on GRI used in this research is found from a website www.globalreporting.org. GRI consists of 3 parts of revealing, including economy, environment and social as the basic for sustainable reporting. Considering the fact that only few companies in Indonesia that have reported their economy, social and environmental performance in a form of sustainability reporting, this research is then limited only to the data found on company 
annual report. This is done also to avoid a gap between companies that have done sustainability reporting and those who have not. In this research the writer is interested in tobacco companies listed in Indonesia stock exchange in the year of 2010-2017, due to its large number of people who have become a market with high consumerism level. This has made many companies grow rapidly in Indonesia; one of them is Tobacco Companies. However, the existence of Tobacco Companies in Indonesia has raised many controversies and become dilemmatic as to their both negative and positive impacts. In one side, tobacco companies contribute to the financial benefits for the country through their tax and have recruited many workers. On the other hands, its existence along with its products and marketing efforts increase the cigarettes consumption and decrease life quality such as damaging health because cigarettes contain many toxic substances for human body. In accordance with the regulation applied and as a form of concern to stakeholders, tobacco companies have social responsibilities such as:

Table 1 DATA OF ACTIVITY FROM CORPORATE SOCIAL RESPONSIBILITY ON TOBACCO COMPANIES LISTED IN INDONESIA STOCK EXCHANGE, PERIOD OF 2010-2017

\begin{tabular}{lll}
\hline No & Company Code & CSR Activity \\
\hline 1. & GGRM & $\begin{array}{l}\text { Creating working opportunity, education, sports, medical service, and religious activity, environmental and its } \\
\text { surroundings activity, social aid and disaster management, traditional culture activity, healthy life, and healthy } \\
\text { safety work and environment. }\end{array}$ \\
& & $\begin{array}{l}\text { Local people empowerment, education, environment preservation, disaster management, healthy safety and work } \\
\text { environment, quality control and product, women empowerment, good practice of farming and farm worker, also } \\
\text { society social development. } \\
\text { Environment, empowerment and initial organization, social life, disaster management, continual environment } \\
\text { and farm preservation also empowerment charity organization, goods. Service responsibility, and environment, } \\
\text { health and security. }\end{array}$ \\
3. & RMBA &
\end{tabular}

(Source: Annual Report, data processing result, 2018)

From the Table above, it can be seen that the cigarette sub-sector in Indonesia is a company that is aggressively utilizing corporate social responsibility programs for business reputation development by carrying out its obligations in CSR disclosure in its business activities. CSR programs carried out by cigarette companies generally base their CSR programs on the concept of development sustainable with Triple Bottom Lines, namely preserving the environment, providing benefits to the community, and maintaining the growth of the company. And the CSR program that has been implemented is based on a framework of five pillars. The five pillars which include education, health, economy, socio-culture, religion, sports, and security, commonly called community development, are carried out alongside sustainable development programs. Through CSR activity, company's performance condition is expected to have a good development. The development of a company is a part of financial annual reports which include income report, balance or other financial report. In other words, financial report is a tool to describe or assess financial condition of a company on a certain period. The result of this assessment is very useful for certain parties who have direct connection or to those who are going to invest their money to a certain company. A company is expected to improve their performance in order to sustain their financial position both in crisis time and in a tight competition. A company's prospect can be seen from profitability and risk level as well as the probability of company undergoes financial difficulties or bankruptcy. Data gained from income report of tobacco sub sector company during observation period is shown as follows:

Table 2 CSR TOTAL REVEALING BASED ON INDICATORS IN GRI 3 PERIOD OF 2010-2017

\begin{tabular}{|c|c|c|c|}
\hline Year & GGRM & HMSP & RMBA \\
\hline 2010 & 56 & 67 & 51 \\
\hline 2011 & 45 & 56 & 61 \\
\hline 2012 & 51 & 49 & 53 \\
\hline 2013 & 49 & 51 & 56 \\
\hline 2014 & 47 & 58 & 52 \\
\hline 2015 & 61 & 53 & 45 \\
\hline 2016 & 55 & 57 & 52 \\
\hline 2017 & 57 & 61 & 49 \\
\hline
\end{tabular}




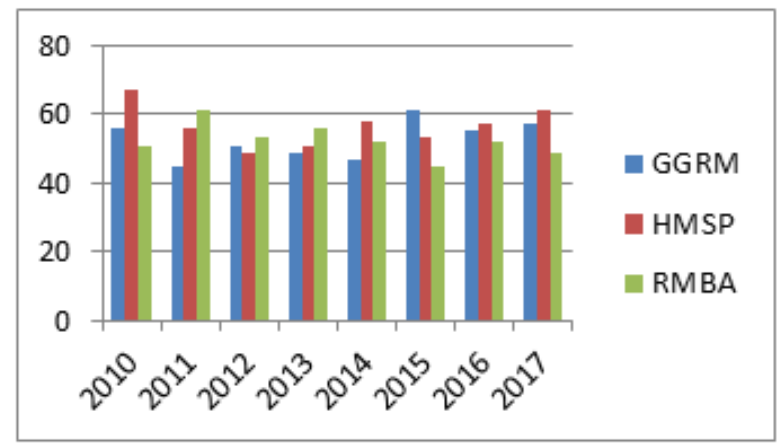

Figure 1 Data on CSR Total Revealing Based on Indicators in GRI 3 at Indonesian Public Listed Tobacco Companies Period of 2010-2017 (Source: idx.co.id (Data Processing Results, 2018))

Table 3 DATA ON NET INCOME (LOSS) AT INDONESIAN PUBLIC LISTED TOBACCO COMPANIES PERIODE OF 2010-2017 (IN MILLIONS RUPIAH)

\begin{tabular}{llll}
\hline Year & GGRM & HMSP & RMBA \\
\hline 2010 & 4.214 .789 & 6.422 .748 & 218.621 \\
2011 & 4.958 .102 & 8.064 .426 & 305.997 \\
2012 & 4.068 .711 & 9.945 .296 & $(323.351)$ \\
2013 & 4.383 .932 & 10.818 .486 & $(1.023 .985)$ \\
2014 & 5.432 .677 & 10.181 .083 & $(1.687 .866)$ \\
2015 & 6.452 .834 & 10.363 .308 & $(1.638 .538)$ \\
2016 & 6.672 .682 & 12.762 .229 & $(2.085 .811)$ \\
2017 & 7.755 .347 & 12.670 .534 & $(480.063)$ \\
\hline
\end{tabular}

(Source: idx.co.id, data processing results, 2018)

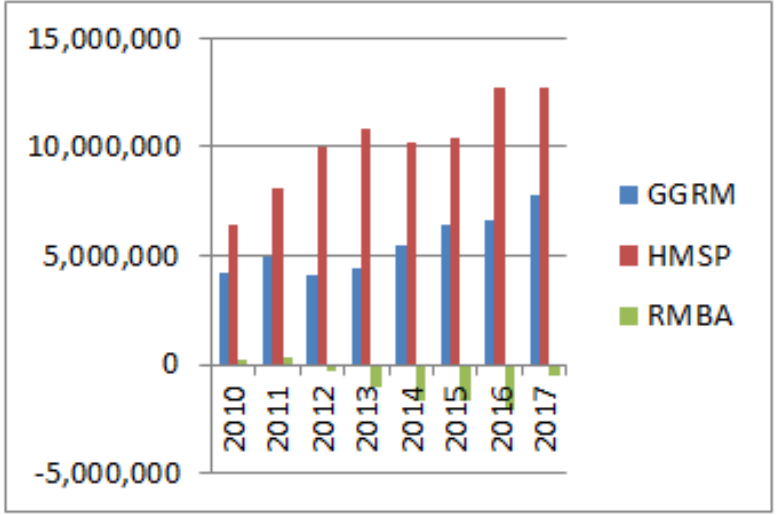

Figure 2 Data on Net Income (loss) at Indonesian Public Listed Tobacco Companies Period of 2010-2017 (in Millions Rupiah) (Source: idx.co.id (Data Processing Results, 2018))

Based on the data in Table 2 and 3 also presented in Figure 1 and Figure 2 above, it is shown that tobacco companies have done their CSR activity, but their financial conditions do not show an improvement. It can be seen in the loss done by PT Bentoel Internasional Internasional Investama Tbk (RMBA) from 2012 until 2017. According to Yusuf, Williams, and Yuwono (2007) stating that "The application of CSR is believed to be able to improve company performance, where investors tend to invest in companies that carry out CSR activities. Because companies that have social concerns can use social responsibility information as one of the company's competitive advantages. In addition, CSR is considered to be able to help improve the company's financial performance, reduce its operating costs, improve its brand and reputation, increase sales and customer loyalty, produce higher product productivity and quality, attract and retain employees, access capital, and help ensure safety product and reduce the legal obligations of an organization ". Or by doing so when a company carries out CSR activities it is considered a cost center and not a long-term investment or a business strategy of a company. And there may be a decline in profits or losses due to other factors that affect company activities, such as increases in raw material prices or customs. 
The difference between this study and previous research related to CSR is located on the dependent variable which consists of four financial ratios, so specifically it will make four research models, research samples for cigarette companies that have IPOs in 1990 and in longer period observations, namely years of observation 2010-2017. This study uses the cigarette sub-sector company due to the controversy over the existence of cigarette companies in Indonesia due to its products and marketing increasing people's consumption of cigarettes and reducing the quality of life and health of the people themselves so that companies need to disclose CSR as a reciprocal to the surrounding environment.

These differences make this study focus on the current ratio, debt ratio, net profit margin, and return on assets. Of the several components of the financial statements can be assessed the achievements of the company, the effectiveness and efficiency of operational activities that have been affected by these CSR activities. And the strengths or weaknesses that are owned by the company and what causes the current ratio, the debt ratio, return on ratio, and the net profit ratio experience up and down from CSR activities or not.

Therefore, the writer would like to prove whether there is any effect of CSR on Current Ratio, Debt Ratio, Net Profit Margin, and Return on Asset on tobacco companies listed in Indonesia stock exchange (Period of observation 2010-2017).

\section{Research Purposes}

The aims of this research are:

1. To examine the effect of CSR which is proxied by Economy Performance (X1), Environment Performance (X2), Social Performance (X3) on Current Ratio (Y1) on tobacco companies listed in Indonesia stock exchange, in year 2010-2017 of the observation.

2. To test the effect of CSR which is proxied by Economy Performance (X1), Environment Performance (X2), Social Performance (X3) on Debt Ratio (Y2) on tobacco companies listed in Indonesia stock exchange, in year 2010-2017 of the observation.

3. To test the effect of CSR which is proxied by Economy Performance (X1), Environment Performance (X2), Social Performance (X3) on Net Profit Margin (Y3) on tobacco companies listed in Indonesia stock exchange, in year 2010-2017 of the observation.

4. To test the effect of CSR which is proxied by Economy Performance (X1), Environment Performance (X2), Social Performance (X3) on Return On Asset (Y4) on tobacco companies listed in Indonesia stock exchange, in year 2010-2017 of the observation.

\section{LITERATURE REVIEW}

The standards for disclosure of CSR that are developing in Indonesia refer to the standards applied by the GRI (Global Reporting Initiative). The GRI standard was chosen because it focused more on disclosure standards for various economic, social and environmental performance of the company with the aim of improving the quality and utilization of sustainability reports (Global Reporting Initiative, 2012).

The assessment was carried out in measuring the extent of CSR disclosure by giving a score of 1 and 0 . Where the value of 0 for items that were not disclosed and the value of 1 for items revealed by the company (Jennifer Ho \& Taylor, 2007). If the company discloses CSR activities in full, the maximum value achieved is 79. CSRI calculation formula is as follows:

$$
\operatorname{CSDI} \mathrm{j}=\frac{\sum \mathrm{XIj}}{\mathrm{nj}}
$$

Information:

CSRIj: Corporate Corporate Responsibility Disclosure Index j.

$\mathrm{n} \mathrm{j}$ : Number of items for company $\mathrm{j}, \mathrm{nj}=79$ (maximum score).

$\sum X \mathrm{Xij}$ : The total amount of CSR disclosure by the company.

$1=$ if the item is disclosed; $0=$ if the item is not disclosed. Thus, $0<\operatorname{CSRI~} \mathrm{j}<1$.

Current Ratio is a ratio to measure a company's ability to pay short-term liabilities or debts that are immediately due when billed as a whole. In other words, how much current assets are available to cover short-term liabilities that are immediately due. 


$$
\text { Current Ratio }=\frac{\text { Current Assests }}{\text { Current Liabilities }} \times 100 \%
$$

Debt Ratio is a debt ratio used to measure the ratio between total debt and total assets. In other words, how much the company's assets are financed by debt or how much the company's debt affects the management of assets.

$$
\text { Debt Ratio }=\frac{\text { Total Debt }}{\text { Total Assets }} \times 100 \%
$$

According to Fahmi (2015), Net Profit Margin is a ratio that shows the stability of the unit to generate gains at a special sales level. High profit margin is preferred because it shows that the company gets a good result that exceeds the cost of goods sold.

$$
\text { Net Profit Margin }=\frac{\text { Net Profit }}{\text { Sale }} \times 100 \%
$$

The Return on Assets ratio looks at the extent to which the investment invested has been able to provide returns as expected. And the investment is actually the same as the company's assets that are invested or placed.

$$
\text { Return on Investment }=\frac{\text { EAT }}{\text { Total Assets }} \times 100 \%
$$

\section{METHODOLOGY}

Research methodology used in this research is panel data analysis. The research object as the independent variable is CSR which is proxied by Economy Performance (X1), Environment Performance (X2), Social Performance (X3) and the dependent variables are Current Ratio (CR), Debt Ratio (DR), Net Profit Margin (NPM), Return on Asset (ROA).

The research subjects are three tobacco companies listed in Indonesia stock exchange, period of 2010-2017. In this research non probability sampling with purposive/judgment sampling technique is used. The criteria include:

1. All companies of consumption goods industry with tobacco sub sectors listed in Indonesia stock exchange period of 2010-2017.

2. Companies that have issued report of CSR or Annual Report period of 2010-2017.

3. Companies with complete data on the variables used in this research.

Based on the sampling method, the data used is a secondary data, that is data research resource obtained indirectly through media (obtained or recorded from another party). Secondary data normally are evidence, record or historical report in a form a published archive. Data used in this research is annual financial report from tobacco companies through www.idx.co.id which has been audited during the period of 2010-2017. Data analysis procedure is described through Figure 3.

\section{Data Collection}

The researchers collected the data about company profile, financial report and company annual report under the tobacco sub sectors from 2010 until 2017. In processing the data, the steps taken by the researcher include analyzing the companies' annual reports to understand CSR disclosure. This research used GRI because it is more comprehensive in assessing the activity of CSR in one company. In this research, the researcher used 79 items of disclosure which consist of indicators for economy (9 items), environment (30 items), human resource (14 items), human rights (9 items), social (8 items), and product (9 items) with maximum disclosure score of 1 (Servaes \& Tamayo, 2013). 
Flow Chart Panel Data Analysis Process

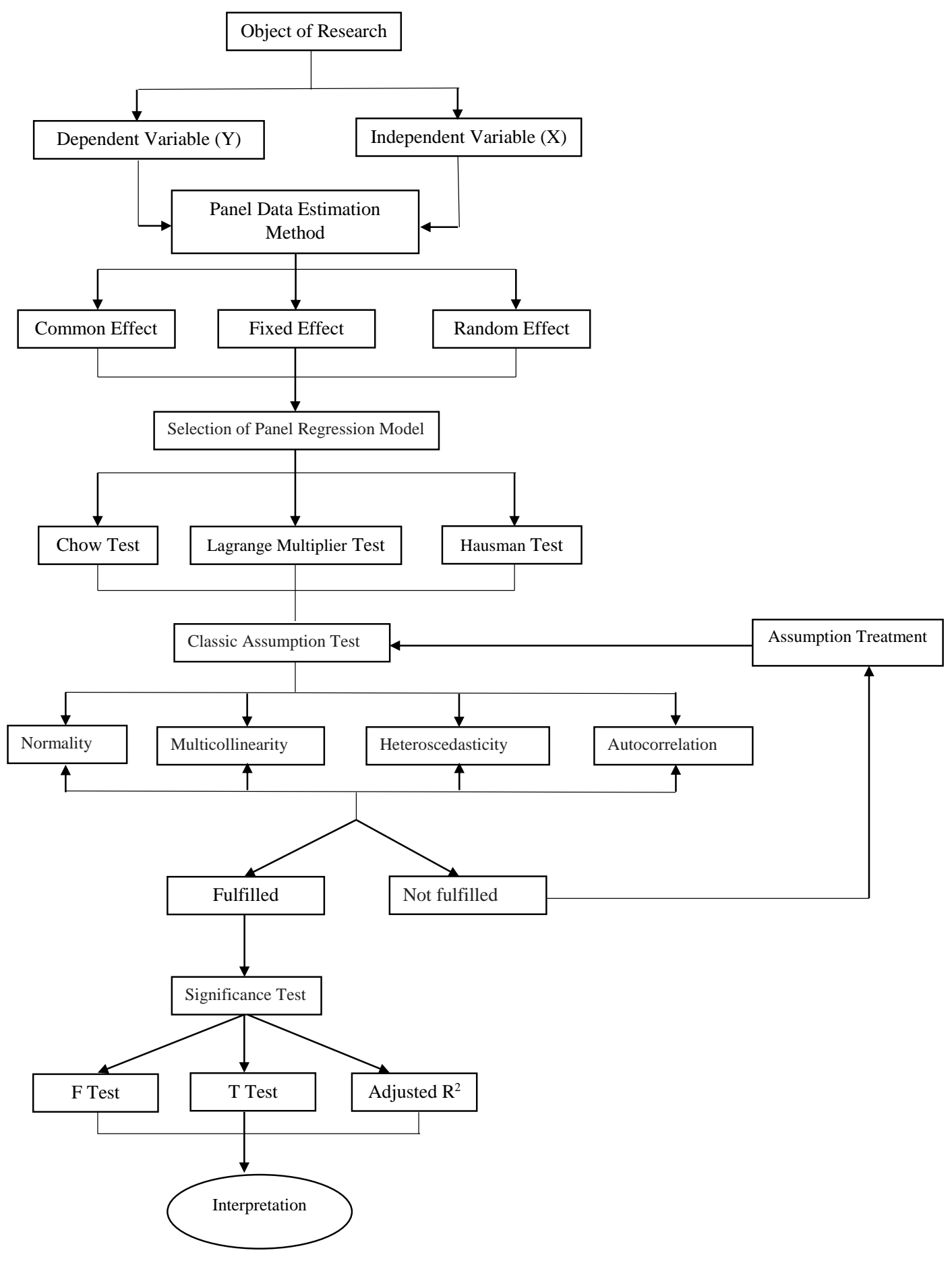

Figure 3 Diagram of Data Panel Analysis Procedure

\section{RESULTS}

Data Panel Model for Assessing the Effect of X1 X2 and X3 on Current Ratio (CR)

Based on the result of data panel analysis using EViews 9 trial version, the best model was obtained by doing Chow test to compare PLS FEM model, with this hypothesis: 
Ho : Model follows Pooled Least Square.

H1 : Model follows Fixed Effect Model.

Table 4 CHOW TEST TO COMPARE PLS AND FEM MODEL

\begin{tabular}{llll}
\hline Effects Test & Statistic & d.f. & Prob. \\
\hline Cross-section $F$ & 3.132104 & $(2,18)$ & 0.0680 \\
Cross-section Chi-square & 7.167133 & 2 & 0.0278 \\
\hline
\end{tabular}

Redundant Fixed Effects Tests

Pool: PERUSAHAAN

Test cross-section fixed effects

From Chow test it can be seen that $p$-value is $(0.068)<0.10$. So it can be concluded that the most suitable model is Fixed Effect Model (FEM). Parameter estimation result using FEM method is as follow:

Table 5 CHOW TEST TO COMPARE PLS AND FEM MODEL

\begin{tabular}{lllll}
\hline Variable & Coefficient & Std. Error & $t$-Statistic & Prob. \\
\hline C & 0.000435 & 0.003192 & 0.136399 & 0.8931 \\
D_X1? & 0.000470 & 0.002694 & 0.174627 & 0.8634 \\
D_X2? & 0.001479 & 0.000963 & 1.535746 & 0.1430 \\
D_X3? & 0.000186 & 0.000649 & 0.286038 & 0.7783 \\
Fixed Effects (Cross) & & & \\
_GGRM-C & 0.001299 & & \\
_HMSP-C & -0.005039 & & \\
_RMBA-C & 0.003903 & & \\
Effects Specification & & & \\
Cross-section fixed (dummy variables) & & & \\
$R$-squared & 0.198069 & Mean dependent var & 0.000491 \\
Adjusted $R$-squared & -0.037793 & S.D. dependent var & 0.014965 \\
S.E. of regression & 0.015245 & Akaike info criterion & -5.309693 & \\
Sum squared resid & 0.003951 & Schwarz criterion & -5.013477 & \\
Log likelihood & 67.06147 & Hannan-Quinn criter. & -5.235196 \\
$F$-statistic & 0.839765 & Durbin-Watson stat & 1.796908 \\
Prob $F$-statistic) & 0.539809 & & \\
Dependent Variable: D_BX_CR? Method: Pooled Least Squares: Sample: 1 8: Included observations: 8 &
\end{tabular}

Based on simultaneous test result of Model FEM, it is said that overall variables of X1, X2, and X3 do not have simultaneous effects on the score for CR $(F$-statistic $=0.540>\alpha=0.10)$. The same result is also shown by partial test (uji-t), which shows that each independent variables statistically do not have any significant effects on CR at significance level of $(\alpha) 10 \%$. R-Square Model value is at 0,198 which shows that only $19,8 \%$ of CR diversity can be explained by variables X1, X2, and X3 while the rest are explained by other variables outside the model. Estimation result equation model is as follows:

$\hat{a} Y_{i t}=0.0004+0.0005 \mathrm{X} 1_{i t}+0.0015 \mathrm{X} 2_{i t}$

$+0.0002 \mathrm{X}_{i t}+0.0013 \mathrm{D}_{G G R M}$

$-0.0050 \mathrm{D}_{H M S P}+0.0039 \mathrm{D}_{R M B A}$

With:

$\hat{Y}_{i t}$ : Current Ratio of company in the- $i$ of year the $-t$.

$\mathrm{X} 1_{i t}$ : CSR with Economy performance for company the- $i$ year the- $t$.

$\mathrm{X} 2_{i t}$ : CSR with Environment performance for company the $-i$ year the- $t$.

$\mathrm{X} 3_{i t}$ : CSR with social performance for company the -i year the- $t$.

$\mathrm{D}_{i}$ : Constanta Value (Individual Effect) in every company the $-i$, with GGRM, HMSP and RMBA

\section{Data Panel Model for Assessing the Effect of X1 X2 and X3 on Debt Ratio (DR)}

Based on data panel analysis using Eviews 9 trial version, it was found the best model according to Chow test to compare PLS and FEM model, with this hypothesis: 
Ho : Model follows Pooled Least Square.

H1 : Model follows Fixed Effect Model.

Table 6 CHOW TEST TO COMPARE PLS AND FEM MODEL

\begin{tabular}{llll}
\hline Effects Test & Statistic & $d . f$. & Prob. \\
\hline Cross-section $F$ & 15.835337 & $(2,18)$ & 0.0001 \\
Cross-section Chi-square & 24.361030 & 2 & 0.0000 \\
\hline Ren
\end{tabular}

Redundant Fixed Effects Tests; Pool: PERUSAHAAN; Test cross-section fixed effects

Based on Chow test, $p$-value is $(0.0001)<0.10$, which means that the most suitable model to be used is FEM. Parameter estimation result using FEM method is as follows:

Table 7 DATA PANEL MODEL FOR ASSESSING THE EFFECT OF X1 X2 AND X3 ON DEBT RATIO (DR)

\begin{tabular}{|c|c|c|c|c|}
\hline Variable & Coefficient & Std. Error & $t$-Statistic Prob. & \\
\hline $\mathrm{C}$ & 57.30890 & 19.70527 & 2.908303 & 0.0094 \\
\hline $\mathrm{X} 1$ ? & 3.916424 & 3.102771 & 1.262235 & 0.2230 \\
\hline $\mathrm{X} 2$ ? & -1.446046 & 1.181394 & -1.224016 & 0.2367 \\
\hline $\mathrm{X} 3$ ? & -0.194519 & 0.391277 & -0.497138 & 0.6251 \\
\hline \multicolumn{5}{|l|}{ Fixed Effects (Cross) } \\
\hline _GGRM-C & -21.85680 & & & \\
\hline _HMSP-C & -15.35230 & & & \\
\hline _RMBA-C & 37.20910 & & & \\
\hline \multicolumn{5}{|l|}{ Effects Specification } \\
\hline \multicolumn{5}{|c|}{ Cross-section fixed (dummy variables) } \\
\hline \multicolumn{5}{|l|}{ Weighted Statistics } \\
\hline$R$-squared & 0.625977 & Mean dependent var & 91.34486 & \\
\hline Adjusted $R$-squared & 0.522082 & S.D. dependent var & 58.52082 & \\
\hline S.E. of regression & 18.90762 & Sum squared resid & 6434.965 & \\
\hline$F$-statistic & 6.025083 & Durbin-Watson stat & 1.826577 & \\
\hline $\operatorname{Prob}(F$-statistic $)$ & 0.001911 & & & \\
\hline \multicolumn{5}{|l|}{ Unweighted Statistics } \\
\hline$R$-squared & 0.670739 & Mean dependent var & 55.65471 & \\
\hline Sum squared resid & 7536.501 & Durbin-Watson stat & 2.436102 & \\
\hline
\end{tabular}

Based on simultaneous test of FEM model, overall result of variables X1, X2, and X3 have an effect on the value of DR $(F$-statistic $=0.0019<\alpha=0.10)$. Meanwhile, from partial test $(t$-test $)$, it shows that each independent variable statistically does not have a significant effect on DR on significance level $(\alpha)$ of $10 \%$.

R-Square Model value is 0.626 which shows that only $62.6 \%$ of DR diversity can be explained by variables X1, X2, and $\mathrm{X} 3$ while the rest is explained by other variables outside the model. Estimation result equation model is as follows: $\hat{Y}_{i t}=57.3089+3.9164 \times 1_{i t}$

$-1.4460 \mathrm{X} 2_{i t}-0.1945 \mathrm{X} 3_{i t}$

- $21.8568 \mathrm{D}_{G G R M}-15.3523 \mathrm{D}_{H M S P}$

$+37.2091 \mathrm{D}_{R M B A}$

With:

$\hat{Y}_{i t}$ : Debt Ratio company the-i year the-t

$\mathrm{X}_{1 i}$ : CSR with Economy performance for company the $-i$ year the- $t$

$\mathrm{X} 2_{i t}$ : CSR with Environmental performance for company the $-i$ year the- $t$

$\mathrm{X} 3_{i t}$ : CSR with Social performance for company the $-i$ year the- $t$

$\mathrm{D}_{i}$ : Constanta Value (Individual Effect) in every company the $-i$, with i GGRM, HMSP and RMBA

\section{Data Panel Model to Assess the Effect of X1 X2 and X3 on Net Profit Margin (NPM)}

Based on the result from data panel analysis using Eviews 9 trial version, it was found the best model using Chow test to compare PLS and FEM model, with hypothesis as follows: 
Ho : Model follows Pooled Least Square

H1 : Model follows Fixed Effect Model

Table 8 CHOW TEST TO COMPARE PLS AND FEM MODEL

\begin{tabular}{llll}
\hline Effects Test & Statistic & $d . f$ & Prob. \\
\hline Cross-section $F$ & 39.332707 & $(2,18)$ & 0.0000 \\
Cross-section Chi-square & 40.341214 & 2 & 0.0000 \\
\hline
\end{tabular}

Redundant Fixed Effects Tests Pool: PERUSAHAAN Test cross-section fixed effects

Based on Chow test the value of $p$-value is $(0.000)<0.10$, and it can be concluded that the most suitable model to be used is FEM model. Parameter estimation result using FEM method can be seen as follows:

Table 9 DATA PANEL MODEL TO ASSESS THE EFFECT OF X1 X2 AND X3 ON NET PROFIT MARGIN (NPM)

\begin{tabular}{|c|c|c|c|c|}
\hline Variable & Coefficient & Std. Error & $t$-Statistic & Prob. \\
\hline $\bar{C}$ & -0.600804 & 0.493416 & -1.217641 & 0.2400 \\
\hline D_X1? & -1.029527 & 0.626316 & -1.643781 & 0.1186 \\
\hline D_X2? & 0.289818 & 0.205833 & 1.408024 & 0.1771 \\
\hline D_X3? & 0.034775 & 0.087361 & 0.398062 & 0.6955 \\
\hline \multicolumn{5}{|l|}{ Fixed Effects (Cross) } \\
\hline _GGRM-C & 0.364741 & & & \\
\hline _HMSP-C & 0.826787 & & & \\
\hline _RMBA-C & -1.145936 & & & \\
\hline \multicolumn{5}{|l|}{ Effects Specification } \\
\hline \multicolumn{5}{|c|}{ Cross-section fixed (dummy variables) } \\
\hline \multicolumn{5}{|l|}{ Weighted Statistics } \\
\hline$R$-squared & 0.212781 & Mean dependent var & -0.304740 & \\
\hline Adjusted $R$-squared & -0.018753 & S.D. dependent var & 3.951869 & \\
\hline S.E. of regression & 4.000848 & Sum squared resid & 272.1154 & \\
\hline$F$-statistic & 0.919004 & Durbin-Watson stat & 1.660863 & \\
\hline $\operatorname{Prob}(F$-statistic $)$ & 0.492336 & & & \\
\hline \multicolumn{5}{|l|}{ Unweighted Statistics } \\
\hline$R$-squared & 0.065770 & Mean dependent var & -0.589210 & \\
\hline Sum squared resid & 347.7019 & Durbin-Watson stat & 1.438419 & \\
\hline
\end{tabular}

Based on simultaneous test of FEM model, the overall result from variables $\mathrm{X} 1, \mathrm{X} 2$, and $\mathrm{X} 3$ do not have any effects simultaneously on the value of NPM $(F$-statistic $=0.492>\alpha=0.10)$. Meanwhile from the partial test $(t$-test $)$, it shows that each independent variable statistically does not have a significance effect on NPM on significance level $(\alpha)$ of $10 \%$.

$R$-Square Model value is 0,213 which shows that there is only 21,3\% diversity of NPM that can be explained by variables X1, X2, and X3 while the rest are explained by other variables outside the model. Model of estimation result equation is as follows :

$\hat{Y}_{i t}=-0.6008-1.0295 \mathrm{X} 1_{i t}+0.2898 \mathrm{X} 2_{i t}+0.0348 \mathrm{X} 3_{i t}$

$+0.3647 \mathrm{D}_{G G R M}+0.8268 \mathrm{D}_{H M S P}$

$-1.1459 \mathrm{D}_{R M B A}$

With:

$\mathrm{Y}_{i t}$ : Net Profit Margin company the- $i$ year the- $t$

$\mathrm{X}_{1 i}$ : CSR with economy performance for company the $-i$ year the- $t$

$\mathrm{X} 2_{i t}$ : CSR with Environmental performance for company the- $i$ year the- $t$

$\mathrm{X} 3_{i t}$ : CSR with Social performance for company the $-i$ year the- $t$

$\mathrm{D}_{i}$ : Constanta Value (Individual Effect) in every company the $-i$, with i GGRM, HMSP and RMBA

\section{Data Panel Model to Assess the Effect of X1 X2 and X3 on Return on Asset (ROA)}

Based on the result of data panel using Eviews 9 trial version, it was found the best model using Chow test to compare PLS and FEM model, with hypothesis as follows: 
Ho : Model follows Pooled Least Square

H1 : Model follows Fixed Effect Model

Table 10 CHOW TEST TO COMPARE PLS AND FEM MODEL

\begin{tabular}{llll}
\hline Effects Test & Statistic & d.f. & Prob. \\
\hline Cross-section $F$ & 64.091783 & $(2,18)$ & 0.0000 \\
Cross-section Chi-square & 50.267793 & 2 & 0.0000 \\
\hline
\end{tabular}

Redundant Fixed Effects Tests Pool: PERUSAHAAN Test cross-section fixed effects

Based on Chow test the $p$-value is $(0.000)<0.10$, which can be concluded that the most suitable model to be used is FEM model. Parameter estimation result using FEM method is as follow:

Table 11 DATA PANEL MODEL TO ASSESS THE EFFECT OF X1 X2 AND X3 ON NET PROFIT MARGIN (NPM)

\begin{tabular}{|c|c|c|c|c|}
\hline Variable & Coefficient & Std. Error & $t$-Statistic & Prob. \\
\hline $\mathrm{C}$ & -0.802795 & 0.867833 & -0.925057 & 0.3679 \\
\hline D_X1? & -1.902282 & 1.092752 & -1.740817 & 0.0998 \\
\hline D_X2? & 0.815810 & 0.419967 & 1.942559 & 0.0688 \\
\hline D_X3? & 0.031817 & 0.142731 & 0.222917 & 0.8263 \\
\hline \multicolumn{5}{|l|}{ Fixed Effects (Cross) } \\
\hline _GGRM-C & 0.611167 & & & \\
\hline _HMSP-C & 2.418046 & & & \\
\hline _RMBA-C & -2.952817 & & & \\
\hline \multicolumn{5}{|l|}{ Effects Specification } \\
\hline \multicolumn{5}{|c|}{ Cross-section fixed (dummy variables) } \\
\hline \multicolumn{5}{|c|}{ Weighted Statistics } \\
\hline R-squared & 0.268534 & Mean dependent var & -0.653954 & \\
\hline Adjusted R-squared & 0.053396 & S.D. dependent var & 7.631374 & \\
\hline S.E. of regression & 7.433186 & Sum squared resid & 939.2883 & \\
\hline$F$-statistic & 1.248197 & Durbin-Watson stat & 1.330985 & \\
\hline $\operatorname{Prob}(F$-statistic $)$ & 0.330482 & & & \\
\hline \multicolumn{5}{|l|}{ Unweighted Statistics } \\
\hline$R$-squared & 0.227019 & Mean dependent var & -0.744305 & \\
\hline Sum squared resid & 1281.453 & Durbin-Watson stat & 1.329473 & \\
\hline
\end{tabular}

Based on simultaneous test from FEM model, the overall result from variables $\mathrm{X} 1, \mathrm{X} 2$, and $\mathrm{X} 3$ do not have simultaneous effects on the value of ROA ( $F$-statistic $=0.330>\alpha=0.10)$. while from the result of partial test $(t$-test), it shows that independent variables X1, X2 statistically have significant effects on ROA on significance level $(\alpha)$ of $10 \%$ while independent variable X3 statistically does not have a significance effect on ROA on significance level $(\alpha)$ of $10 \%$.

$R$-Square Model value is 0,269 which shows that only $26.9 \%$ diversity of ROA can be explained by variable X1, $\mathrm{X} 2$, and X3 while the rest can be explained by other variables outside the model.

Estimation result equation Model is as follows:

$\hat{Y}_{i t}=-0.8028-1.9023 \mathrm{X} 1_{i t}+0.8158 \times 2_{i t}$

$+0.0318 \mathrm{X} 3 \mathrm{it}+0.6112 \mathrm{D}_{G G R M}$

+2.4180 DHMSP - $2.9528 \mathrm{D}_{R M B A}$

With:

$\mathrm{Y}_{i} t:$ return on Asset company the -i year the-t

$\mathrm{X} 1_{i t}$ : CSR with Economy performance for company the $-i$ year the- $\mathrm{t}$

$\mathrm{X} 2_{i t}$ : CSR with Environmental performance for company the $-i$ year the $-t$

$\mathrm{X}_{3}$ it : CSR with Social performance for company the $-i$ year the- $t$

$\mathrm{D}_{i}$ : Constanta Value (Individual Effect) in every company the $-i$, with i GGRM, HMSP and RMBA 


\section{DISCUSSION}

Companies as one form of organization generally have certain goals to be achieved in an effort to meet the interests of its members. As a basic goal of a company is a material wealth and commercial benefits. Success in achieving company goals is a management achievement. And according to Fahmi (2015), performance appraisal or company performance is measured because it can be used as a basis for decision-making both internal and external parties, because financial performance is a picture of the success of the company. With the Law on Limited Liability Company (Republic Indonesia, 2007) which came into force on 16 August 2007 concerning awareness of the need to protect the environment in Indonesia. This encourages the CSR concept that a company in carrying out activities and decision making is not only based on financial factors such as dividends and profits but also based on social and environmental consequences for the present and future.

This is also supported by the opinion of (Branco \& Rodrigues, 2008) in the legitimacy theory that companies must implement and disclose CSR activities as much as possible so that company activities can be accepted by society. The disclosure is used to legitimize company activities in the eyes of the public, because CSR disclosure will show the level of compliance of a company. And according to Reverte (2009) to be accepted by the community, the company must disclose the company's social activities so that it will guarantee the survival of the company.

This research discusses about the effect of CSR on each financial performance such as Current Ratio, Debt Ratio, Net Profit Margin, and Return on Asset on tobacco companies listed in Indonesia Stock exchange within the observation period of 2010-2017.

Research finding explains that financial performance such as the highest Debt Ratio can be explained by CSR compared with other financial performance in this research. This means that the hope in carrying out CSR activities is to improve the image of the company's products. With an improved product image, it will increase assets with high liquidity value. When a company has assets with high liquidity value, then when the company has debts that are due or at the company in difficult circumstances, it is expected that the company's assets will be able to cover every debt borne by the company.

Table 12 R-SQUARE VALUE FOR CSR ON EVERY FINANCIAL PERFORMANCE

\begin{tabular}{lll}
\hline Financial Performance $(\mathrm{Y})$ & CSR $(\mathrm{X})$ & $R^{2}$ \\
\hline CR & $\mathrm{X} 1, \mathrm{X} 2$ and X3 & $19,8 \%$ \\
DR & $\mathrm{X} 1, \mathrm{X} 2$ and X3 & $62,6 \%$ \\
NPM & $\mathrm{X} 1, \mathrm{X} 2$ and X3 & $21,3 \%$ \\
ROA & $\mathrm{X} 1, \mathrm{X} 2$ and X3 & $26,9 \%$ \\
\hline
\end{tabular}

\section{LIMITATION OF THE STUDY}

Subject of this research is limited only on tobacco sub sectors, therefore it cannot be used to find out the effect happens on other fields of trading, such as food and beverage industry, or other sector that shows continuous company report. The research only used eight periods because of the limited annual data reports which are hard to find and only used four dependent variables. Data panel approach model used in this research is limited with so many cross-section data which refers to the number of companies so that during the analysis, PLS and FEM method were used.

\section{CONCLUSION}

From all four financial performances it can be said that CSR can only explain about the quantity of Debt Ratio which is around 62,6\%. While for other financial performance quantity such as Curret Ratio, Net Profit Margin and Return on Asset, CSR has not been yet capable in explaining it.

Overall it can be concluded that CSR activity cannot exactly describe financial performance of a company. It can be seen from hypothesis test result ( $F$-test, $t$-test) and goodness measurement of data panel model in a form of determination coefficient ( $R$-Square). For further research, it is necessary to add the latest CSR indicators, other variables beside of CSR, increase the number of companies and longer time periods used.

\section{REFERENCES}

Branco, M. C., \& Rodrigues, L. L. (2008). Factors influencing social responsibility disclosure by portuguese companies. 
Journal of Business Ethics, 83(4), 685-701. doi:https://doi.org/10.1007/s10551-007-9658-z

Carroll, A. B., \& Shabana, K. M. (2010). The business case for corporate social responsibility: A review of concepts, research and practice. International Journal of Management Reviews, 12(1), 85-105. doi:https://doi.org/10.1111/ j.1468-2370.2009.00275.x

Dianita, M. (2015). Role of the internal auditor influence and good corporate governance in banking financial performance against state owned corporation. International Journal of Business and Administrative Studies, 1(4), 176- 179. doi:https://doi.org/10.20469/ijbas.10006-4

Fahmi, I. (2013). Organizational behavior theory, applications, and cases. Bandung, Indonesia: Alfabeta.

Fahmi, I. (2015). Strategy and application management. Bandung, Indonesia: Alfabeta.

Global Reporting Initiative. (2012). Public sector sustainability reporting. Retrieved from https://bit.ly/2Gc2wzM (accessed on 14 July, 2017)

Hang, H. T. T. (2015). The effect of capital structure on corporate performance: Evidence in Vietnam. International Journal of Business and Administrative Studies, 1(2), 68-77. doi:https://doi.org/10.20469/ijbas.10004-2

Ikatan Akuntan Indonesia. (1998). Financial accounting standards. Retrieved from https://bit.ly/2rcDQQL (accessed on 14 June, 2016)

Jennifer Ho, L.-C., \& Taylor, M. E. (2007). An empirical analysis of triple bottom-line reporting and its determinants: Evidence from the United States and Japan. Journal of International Financial Management \& Accounting, 18(2), 123-150. doi:https://doi.org/10.1111/j.1467-646x.2007.01010.x

Ketsiri, K., \& Pajongwong, P. (2016). Knowledge and understanding of accountants toward rules for calculating net income for corporate income tax by section 65 ter in Thailand. International Journal of Business and Economic Affairs, 1(1), 67-73. doi:https://doi.org/10.24088/ijbea-2016-11009

Kotler, P., \& Lee, N. (2008). Corporate social responsibility: Doing the most good for your company and your cause. New York, NY: John Wiley \& Sons.

Mohamed, W. S., \& Arafa, I. M. (2016). Investigating corporate social responsibility disclosure by banks from institutional theory perspective. Journal of Administrative and Business Studies, 2(6), 280-293. doi:https:// doi.org/10.20474/jabs-2.6.3

Republic Indonesia. (2007). Limited liability law no. 40. Retrieved from https://bit.ly/2MDt4LF (accessed on 14 July, 2008)

Reverte, C. (2009). Determinants of corporate social responsibility disclosure ratings by Spanish listed firms. Journal of Business Ethics, 88(2), 351-366. doi:https://doi.org/10.1007/s10551-008-9968-9

Servaes, H., \& Tamayo, A. (2013). The impact of corporate social responsibility on firm value: The role of customer awareness. Management Science, 59(5), 1045-1061. doi:https://doi.org/10.1287/mnsc.1120.1630

Velasques, M. (2012). Business ethics. New Jersey, NJ: Pearson.

Yoo, J., Lee, M. K., \& Lee, W. S. (2016). Asymmetrical corporate responses to economic information: Applying the firm size effect. Journal of Administrative and Business Studies, 2(1), 29-34. doi:https://doi.org/10.20474/jabs-2.1.4

Yusuf, E. Z., Williams, L., \& Yuwono, Y. (2007). Marketing management: Indonesian case study. Lembaga Manajemen Pusat Pengembangan Manajemen (PPM): Penerbit Pusat. 